See discussions, stats, and author profiles for this publication at:

https://www.researchgate.net/publication/235273082

\title{
Strategic philosophy and management level
}

Article in Management Decision · February 2005

DOI: $10.1108 / 00251740510581894$

CITATIONS

1 author:

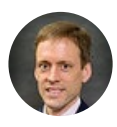

John Alan Parnell

University of North Carolina at Pembroke

130 PUBLICATIONS 2,007 CITATIONS

SEE PROFILE

Some of the authors of this publication are also working on these related projects:

Project Firm Performance View project

All content following this page was uploaded by John Alan Parnell on 03 August 2014.

The user has requested enhancement of the downloaded file. 


\title{
Strategic philosophy and management level
}

\section{Philosophy and management level}

\author{
John A. Parnell
}

\author{
School of Business, University of North Carolina, Pembroke, \\ North Carolina, USA
}

\begin{abstract}
Purpose - To examine how a manager's strategic philosophy is influenced by his or her management level in the organization.

Design/methodology/approach - Scales are developed to measure managers' philosophical perspectives along three key dimensions and tested with 289 managers in the United States. Refined scales are administered to 237 managers.

Findings - A manager's level in the organization influences his or her strategic philosophy. As compared to middle-and lower-level managers, top managers were more likely to view strategy formulation as an art, to emphasize strategic flexibility as opposed to strategic consistency, and to see strategy as top-down process.

Research limitations/implications - No single strategic philosophy is suggested as the optimal perspective. In addition, there are multiple possible explanations for the findings. Additional research is needed. Recognizing differences in strategic philosophy can also enhance training and development efforts at the lower and middle management levels.

Practical implications - Findings lend support to the notion that one's strategic philosophy is not independent of one's management position and suggests that managers at each level may adopt perspectives that facilitate the managerial responsibilities at that level.

Originality/value - This paper provides empirical evidence for a nexus between management level and strategic philosophy, a stream of research that received only limited research interest to date.
\end{abstract}

Keywords Corporate strategy, Philosophy, Decision making, Senior managers, Middle managers

Paper type Research paper

Strategic management remains an intuitive and philosophical undertaking (Beaver, 2003; Brockmann and Anthony, 2002). Executives have at their disposal a wealth of information and research designed to help them make the "right decisions", but strategic choices often reflect their views on the nature of strategy and how it should be formulated (Kotey and Meredith, 1997; Frishammar, 2003). Differences in perspective not only occur among specific managers, but across groups of managers, including those at various levels of management (Marginson, 2003). Specifically, there is anecdotal evidence to suggest that lower-, middle-, and upper-level managers - as well as non-managers - may not share philosophical views of the strategy process due to differences in experience and responsibilities associated with their respective positions.

This paper outlines three ostensible philosophical contradictions that influence strategic decision-making: management as an art or science, strategic emphasis on consistency or flexibility, and strategy as a top-down or a bottom-up approach. It is suggested that one's strategic philosophy along these lines may be a function of a number of factors. In this study, differences in predispositions are explored across management levels. Implications for managers and directions for future research are also outlined.

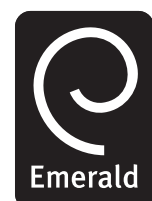

\footnotetext{
Management Decision Vol. 43 No. 2, 2005 (C) Emerald Group Publishing Limited DOI $10.1108 / 00251740510581894$
} 
$\mathrm{MD}$

43,2

158

\section{The notion of strategic philosophy}

Strategy is about making choices (Porter, 1985). Because the systematic collection of relevant information concerning the organization's environment is at best an inexact science, strategic managers are inevitably left with varying amounts of uncertainty associated with each strategic alternative they possess. When faced with this dilemma, a strategic manager relies on his or her personal, subjective perspective of strategy as it related to the organization and its environment (Hendry, 2000; Smircich and Stubbart, 1985). It is this perspective that constitutes one's strategic philosophy.

Within this context, strategic philosophy refers to one's personal views concerning the nature of organizational strategy based on intuition, reason, and experience. One's strategic philosophy can be influenced by a variety of personal factors. The personalities and self-interests of managers at middle and upper levels have been linked to strategy formulation in a number of empirical studies (Guth and Macmillan, 1986; Walsh and Fahey, 1986). More specifically, strategy formulation is linked to the top executive's personal philosophy of how the organization should function (Hambrick and Fredrickson, 2001). By its very nature, the notion of philosophy implies the existence of competing ideals and multiple perspectives on an issue (Barney, 2001; Priem and Butler, 2001).

One should not view the influence of strategic philosophy as counter to the concept of rational strategic planning for two key reasons. First, whereas a rational perspective seeks an objective "best decision" among alternatives, a philosophical perspective recognizes that a certain degree of subjectivity may also be involved, acknowledging the role of the "philosophical perspective" of the strategic decision maker. However, both perspectives are concerned with decision-making that maximizes organizational performance over a given time frame. Although the majority of strategy research appears to have adopted a rational perspective, integrating philosophical considerations into the discussion acknowledges the existence of subjectivity that is pervasive within strategic decision-making.

Second, while there may be multiple valid perspectives on a given strategic issue, it is plausible that there may be no "single best answer" or that one perspective may be preferable in some, but not all situations. Within this context, one philosophical perspective may be objectively superior to another within certain contexts.

The following sections outline three key dimensions of strategic philosophy in greater detail: management as an art or science, strategic emphasis on consistency or flexibility, and strategy as a top-down or a bottom-up approach. Subsequent sections present propositions concerning anticipated differences across management levels, and describe scales used to measure each dimension. Findings are discussed, followed by conclusions and prospects for future research.

\section{Strategy as an art or science}

The art versus science debate is one of the most fundamental issues in strategy formulation. While some may argue that the art-science discussion is merely an academic dispute, one's perception of the strategy phenomena - and more specifically the process of strategy formulation - is a key building block of strategy. In other words, one's view of how the strategy process should function is inseparable from one's view of what the strategy should be. Most scholars and practitioners acknowledge that strategy, like management in general, is both an art and a science. 
However, the assumption that executives act on this hybrid perspective remains largely unquestioned.

The difference between the art and science interpretations of strategy is substantial. According to the art perspective, the lack of environmental predictability and the fast pace of change suggest that the inherent value of strategic planning is limited. Instead, strategists should incorporate substantial creativity and intuition in order to design a comprehensive strategy for the firm (Ford and Gioia, 2000). In contrast, followers of the science perspective see the business environment as largely objective, analyzable, and predictable to a great extent. As such, strategic managers should follow a systematic process of environmental, competitive, and internal analysis, and build the organization's strategy on this foundation.

Most of the strategy literature has traditionally favored the science, or planning model, whereby strategic managers are encouraged to systematically assess the firm's external environment and, based on perceived strengths and weaknesses, evaluate the pros and cons of myriad alternatives before formulating strategy. The search for causal relationships and objectivity are central to the planning model. By definition, strategic managers should be trained, highly skilled analytical thinkers capable of digesting a host of objective data and translating it into a desired direction for the firm.

In contrast, Mintzberg (1987) notion of a craftsman, incorporating individual skill, dedication, and perfection through mastery of detail, embodies represents the artistic approach to strategy making. The strategy artist senses the state of the organization, interprets its subtleties, and seeks to construct the strategy in the same way that a potter molds clay. Further, the strategist's notions of "deliberate" and "emergent" strategies reflect differences between the strategies that emanate from the two schools of thought. Nonetheless, most scholars continued to proceed with the assumption that deliberate strategies are preferred, and emergent strategies invariably result from ineffective planning and/or environmental unpredictability.

The relevance of the philosophical debate between the art and science schools of thought cannot be overstated. "Strategy scientists" tend to minimize or reject altogether the role of imagination and creativity in the strategy process, and do not tend to be receptive to alternatives that emerge from any process other than a comprehensive, analytical approach. "Strategy artists" often view strategic planning exercises as time poorly spent and may not be as likely as those in the science school to make the effort necessary to maximize the value of a formal planning process (Hamel, 1996; Huffman, 2001). Nonetheless, how this supposed contradiction is resolved in practice is unclear.

\section{Strategic consistency and flexibility}

An organization's strategic managers may choose to commit to a strategic course of action for an extended period of time and enjoy the benefits of specialization, expertise, organizational learning, and a clear customer image. Alternatively, an organization can remain flexible so that it does not become committed to products, technology, or market approaches that may become outdated. In a perfect world, organizations commit to predictable, successful courses of action, and strategic change is only incremental. However, outcomes are not always predictable and the environment is dynamic (Grewel and Tansuhaj, 2001).
Philosophy and management level

159 
$\mathrm{MD}$

43,2

160

Empirical research concerning the link between strategic change and organizational performance remains inconclusive (Kraatz and Zajac, 2001). Indeed, a number of studies have concluded that the relationship is quite complex, heavily influenced by factors such as the nature of the change, environmental turbulence, and industry structure (Mezias et al., 2001; Parnell, 1994; Trinh and O'Connor, 2002).

Interestingly, the popular business press often takes both sides of this debate. When traditional firms perform poorly, their strategic managers are exhorted to promote flexibility and strategic renewal to improve profitability. In contrast, when bold strategic changes fail, pundits assert that a company must return to its "core business". Hence, it is easy to migrate freely from one side of the debate to the other, often with convincing empirical and intuitively appealing arguments.

The needs for strategic flexibility or consistency can be debated at least four grounds, as summarized in Table I. Due to the complexity of the issues surrounding this debate, the perspectives outline in Table I are presented in simple terms and should be viewed as such.

First, a strategy tends to yield superior performance when it "fits" with the organization's environment. Without strategic flexibility, an organization cannot adapt to its changing external environment (Parnell, 1997). Even if an organization's strategy and its environment are in concert, an environmental shift may necessitate strategic change to maintain alignment. In addition, changes in competition and technology necessitate a change in the knowledge base within the organization if it is to prosper. The state of the environment is not always fully understood by strategy formulators, and top managers may be most likely to contemplate a strategic change when perceived environmental uncertainty is high.

In contrast, however, a change in any key strategic, environmental, or organizational factor may entice strategic managers in a business to modify its strategy to incorporate these changes. However, since such variables are constantly evolving, this is challenging process, and strategic inaction may minimize uncertainty. Indeed, a strategic change is most risky when competitors are better equipped to respond if it is deemed successful (Wernerfelt and Karnani, 1987). As such, strategic change can challenge the assumptions of all organizational members and may be difficult to implement even with employees' support (Saffold, 1988).

\begin{tabular}{|c|c|c|}
\hline Broad strategic question & Strategic flexibility perspective & Strategic consistency perspective \\
\hline $\begin{array}{l}\text { How can organizations address } \\
\text { rapid environmental change? }\end{array}$ & $\begin{array}{l}\text { Change the strategy to align with } \\
\text { the environment }\end{array}$ & $\begin{array}{l}\text { Reduce uncertainty by } \\
\text { maintaining a consistent } \\
\text { strategy }\end{array}$ \\
\hline $\begin{array}{l}\text { How important are first mover } \\
\text { advantages? }\end{array}$ & $\begin{array}{l}\text { Very important - the } \\
\text { organization must maintain } \\
\text { flexibility to capitalize on first } \\
\text { mover advantages }\end{array}$ & $\begin{array}{l}\text { Not as important - there is no } \\
\text { guarantee that any first mover } \\
\text { advantages that might be } \\
\text { secured can be maintained }\end{array}$ \\
\hline $\begin{array}{l}\text { Should organizations change } \\
\text { strategies if there are substantial } \\
\text { changes in the resources they } \\
\text { control? }\end{array}$ & $\begin{array}{l}\text { Probably so - the strategy } \\
\text { should be changed to align with } \\
\text { the changes in organizational } \\
\text { resources }\end{array}$ & $\begin{array}{l}\text { Not necessarily - even if such } \\
\text { changes utilize resources more } \\
\text { effectively, they can create } \\
\text { confusion among buyers }\end{array}$ \\
\hline $\begin{array}{l}\text { Should the organization change } \\
\text { strategies if performance } \\
\text { declines? }\end{array}$ & $\begin{array}{l}\text { Probably so - maintaining } \\
\text { strategy flexibility facilitates } \\
\text { such strategy change when } \\
\text { necessary }\end{array}$ & $\begin{array}{l}\text { Not necessarily - strategic } \\
\text { change inevitably costs capital } \\
\text { and can further performance } \\
\text { declines }\end{array}$ \\
\hline
\end{tabular}

Table I.

Strategic consistency versus flexibility
Change the strategy to align with Reduce uncertainty by maintaining a consistent strategy

guarantee that any first mover advantages that might be secured can be maintained Not necessarily - even if such effectively, they can create confusion among buyers Not necessarily - strategic and can further performance declines 
Second, flexibility is necessary if an organization is to seek first mover advantages by entering a new market or developing a new product or service prior to its competitors (Gannon et al., 1992; Petersen and Welch, 2000). Being a first mover can help secure access to scarce resources, increase the organization's knowledge base, and result in substantial long-term competitive advantage, especially when switching costs are high (Lieberman and Montgomery, 1988). Maintaining strategic consistency can preclude movement into attractive strategic domains (Mascarenhas, 1992).

However, even when strategic change results in a successful new product or service, there is no assurance that this success can be maintained. In fact, competitors may distort consumer perceptions and reap the benefits of the initial strategic change. For example, when a consumer goods company implements an "imitation strategy" (Foxman et al., 1990), consumers may purchase the imitation product thinking it is the original. If consumers dislike the product, this dissatisfaction can be transferred to the original. On the other hand, if the consumer likes the product, the consumer may realize that the product is an imitator and transfer the positive associations with the original product to that of the imitator. Either scenario can prove costly to the originator (Loken et al., 1986).

Third, even when a firm's environment is relatively stable, strategic change can be attractive when the organization's set of unique human, physical, capital, and informational resources change (Barney, 2001; Lado et al., 1992). Resource shifts necessitating strategic change may be more prevalent in some organizations than in others (Hitt et al., 1998). Following this logic, strategic change can improve an organization's ability to adapt by forcing healthy changes within the business. The initial pain associated with change may be offset by the emergence of a lean, rejuvenated organization with a fresh focus on its goals and objectives.

However, consumer confusion may result from strategic change even then the new strategy represents a better fit with the firm's resources. For example, if a business employing a low cost strategy attempts to switch to a differentiation strategy, its price-oriented customers may become confused and leave in pursuit of another low cost leader, while those willing to pay a premium price for differentiated products may not recognize or positively perceive the strategic change. Many will likely recall remnants of the previous strategy - perhaps advertising campaigns - and may not even consider the organization for future business (Parnell, 1994).

Fourth, strategic change may be necessary if desired performance levels are not being attained by the organization. In many cases, a change in strategy may be required to improve the ability of the business to generate revenues or profits, increase market share, and/or improve return on assets or investment. Indeed, many studies have concluded that declining profitability is the most common catalyst for strategic change (Boeker, 1989; Webb and Dawson, 1991). New chief executives are often recruited to attempt strategic changes upon entering the organization (Greiner and Bhambri, 1989).

In contrast, however, the measures required to implement a change in strategy may necessitate substantial outlays of capital, thereby further denigrating the organization's financial position. Considering the Miles and Snows' (1978) typology as an example, a shift from a prospector or analyzer strategy to a defender strategy may require investments in sophisticated production equipment to lower production costs, a characteristic more important to effective implementation of a defender
Philosophy and management level

161 
$\mathrm{MD}$

43,2

162 strategy. Likewise, a shift from defender or analyzer to prospector may require substantial outlays to develop or enhance research and development facilities.

It is difficult to eschew the merits of either position in the strategic consistency-flexibility debate. The idea that a balance should be struck between flexibility and consistency is intuitively appealing, but such a perspective remains largely undefined.

\section{Top-down and bottom-up approaches to strategy formulation}

Most scholars agree that at least some non-executive-level managers should be involved in the strategy formulation process. The key issue, however, is the most appropriate degree of involvement. Top-down proponents argue that seasoned executives are the only ones in the organization with the collective experience, acumen, and fiduciary responsibility required to chart the strategy. In contrast, bottom-up proponents argue that since middle- and lower-level managers will eventually be charged to implement a strategy, they should play a central role in its development (Currie, 1999; Fenton-O'Creevy, 2001; Thakur, 1998; Wooldridge and Floyd, 1990).

Research has emphasized the role of multiple managers in building the superior performing organization recent years (Markoczy, 2001; Floyd and Wooldridge, 2000), whereas much of the strategy research in the 1970s and early 1980s relied on the top manager for insight into an organization's strategic intentions. Although the concept of middle management involvement in strategy is not a recent phenomenon, however, the last decade has produced evidence to suggest that strategy formulation and implementation can reflect a diverse array of top and middle management inputs (Hart, 1992; Westphal and Fredrickson, 2001). Mintzberg and Waters (1985) notion of deliberate and emergent strategies acknowledges the significant role of top and middle managers in the strategic management process. Strategy synchronization is seen as a team effort, requiring contributions and knowledge from both middle and senior managers (Nichol, 1992).

A bottom-up approach does not necessarily suggest that strategy should emanate from the lowest ranks in the organization. As opposed to top-down, the notion of bottom-up infers a heavy involvement in non-executives in the development of strategic priorities and eventual crafting of the organization's strategy. Although the top-down and bottom-up extremes appear to be mutually exclusive, there is growing evidence that a synthesis is possible (Floyd and Wooldridge, 2000; Westphal and Fredrickson, 2001). However, empirical research on this phenomenon is lacking.

\section{Propositions}

Three propositions - one for each dimension - are developed and tested in this study. The first proposition addresses the art-science conundrum. In general, scientific, rational models of strategic management have been perpetuated in textbooks and journal papers read by scholars and business students. These models promote analytical techniques and quantitative methods as part of a formal process that generates and evaluated strategic alternatives for the organization. Because level of management education is likely to increase with managerial rank, it is believed that managers at higher levels will be more likely to espouse a scientific perspective on the strategy process (Turnbull, 2001). 
P1. Middle and upper managers view strategy more as a science, whereas lower level and non-managers view strategy more as an art.

The second proposition concerns the strategic consistency-flexibility debate. From an implementation perspective, the difficulties associated with strategic change are more acute at the middle level of the organization downward, where such shifts as organizational restructurings, changes in production processes, modifications in new product development processes, and the like are felt (Davis and Fisher, 2002; Hornsby et al., 2002). Executives typically delegate responsibility for strategic change to middle managers who in turn filter such changes down the line. Hence, top managers are more likely to emphasize the value of strategic flexibility.

P2. Upper managers emphasize strategic flexibility, whereas middle, lower and non-managers emphasize strategic consistency.

The third proposition addresses the degree to which non-executives should participate in the strategy process. Ceteris paribus, individuals often believe that the strategy process should be "brought down" at least to their level within the organization (Van Der Velde and Jansen, 1999; Wai-Kwong et al., 2001). In other words, it is expected that middle managers are more likely to value their contribution than top managers, lower managers are more likely to value their contribution than middle mangers, and so on. Hence, the notion of strategy making as a top management process is likely to be more accepted by top managers than by those at other levels.

P3. Managers at higher levels in the organization are more likely to view strategy as a top-down process, whereas lower level and non-managers are more likely to view strategy as a bottom-up process.

\section{Methods}

Developing scales to measure managerial predispositions along the three philosophical dimensions is the first step in testing the propositions. Although some writers have suggested a "middle ground" between two polar extremes in each realm, the competing perspectives are not necessarily mutually exclusive. Hence, it is not sufficient to develop a single scale to measure one's strategic philosophy within a given realm. Instead, two scales are required for each area, resulting in a total of six required to measure the three dimensions proposed herein (Table II).

Between six and ten items were developed as potential measures for each of the six scales. An initial survey of all of the items was administered to 289 managers in the southeastern United States. Following the initial data analysis, a number of items were eliminated based on wording, loading, or redundancy concerns, and four items were selected as measures for each factor. The resulting survey instrument contained 28 items, including four for each of the six scales and four to measure satisfaction with performance (Parnell, 2000).

The final instrument was administered to 237 top, middle, lower level, and non-managers from the southeastern United States, 56 percent $(N=133)$ of whom were male, 44 percent $(N=104)$ female. The mean for years of experience with the current employer was 4.6 , with a range of $1-27$. The mean years of managerial experience was also 4.1, with a range of 1-21. The average age was 30.4 years, with a range of 22-55 years.
Philosophy and management level

163 
$\operatorname{Art}(\alpha=0.699)$

Developing an effective strategy is like crafting a fine piece of art

Imagination and creativity are very important parts of an effective strategy

Science $(\alpha=0.693)$

With proper research and analysis, most aspects of an organization's environment are relatively predictable

Effective strategies usually result from a detailed, systematic formulation process

Consist $(\alpha=0.677)$

Organizations that perform best in the long term usually main consistent strategies through changing times

Successful organizations tend to maintain expertise or competence in a specific area over an extended period of time

Organizations should not react too quickly to environmental changes by instituting major strategic changes

It is important that an organization be seen as unswerving and steadfast in its strategic priorities over time

Flexible $(\alpha=0.697)$

An effective strategy allows the organization to be flexible so that it can change frequently as the environment changes

Successful organizations change strategies frequently, even when performance is not a problem

An organization's strategy should be modified whenever there are significant changes in the strategic resources it controls

Organizations whose strategies are not flexible lack the ability to capitalize on market opportunities

Top-down $(\alpha=0.787)$

The strategy formulation process should be controlled by top managers

Because they are the most experienced, top managers should drive the strategy-making process

To maintain secrecy, it is usually best when top managers avoid discussing much

Table II.

Item wording and results of factor analyzes about the organization's strategy with others in the organization

Bottom-up $(\alpha=0.758)$

Middle-, and lower-level managers should make significant contributions to an organization's strategy

The best strategic ideas often come from organizational members who are not a part of the top management team

Because middle and lower managers are responsible for strategy implementation,

they should be heavily involved in strategy formulation

0.716

0.773

0.732

0.887

Organizational members who have direct contact with customers and production

processes are best equipped to drive the strategy formulation process

Respondents represented a variety of industries. Although this phenomenon introduces some degree of cross-industry variation into the study, the constructs and relationships were hypothesized to be consistent across industries. Although support for such relationships with a cross-industry sample can be more difficult to 
engender, it was pursued in order to lend greater credence to the generalizability of the findings.

\section{Findings}

Application of the principal components (Harman and Jones, 1966) factor extraction technique resulted in single factor loadings in the six scales ranging from 0.614 to 0.892 (Table I). Scholars and statisticians have suggested desired minimum loadings ranging from 0.500 to 0.700 . Coefficient $\alpha$ (Cronbach, 1951) for the scales ranged from 0.677 to 0.787 for the six scales, indicating a moderate level of internal consistency, an important indication of reliability (Kuratko et al., 1990; Peter, 1979). The scale to measure satisfaction with performance produced loadings ranging from 0.641 to 0.886 , with a coefficient $\alpha$ of 0.829 . Factor scores (regression method) were computed to serve as composite measures for each of the factors. Application of the analysis of variance (ANOVA) technique demonstrated significant differences among management levels along each of the six measures (Table III).

Although a form of the relationship between management level and art-science perspective was identified, the first proposition was not supported. Interestingly, a key line of demarcation was identified between middle and top managers, not between lower and middle managers are originally postulated. Specifically, middle managers were the most likely to view strategy as an art, whereas top managers were most likely to see it as a science and least likely to see it as an art.

There are at least two possible explanations for the stark contrast between middle and upper managers. One possibility is that experience - a key difference between middle and upper managers - may influence a manager's art-science perspective more than exposure to formal training. In other words, managers may be more likely to adopt a rational view of strategy as they gain experience and identify practical shortcomings in the artistic perspective.

Another possible explanation is that boards of directors tend to be more conservative in their evaluations of top management's strategic proposals. Because board members may be more likely to support strategies supported by a rational, analytical basis, top managers may "learn" to pursue a formal approach to the strategy process.

The second proposition was supported. As predicted, middle managers were the most likely to emphasize consistency, whereas top managers were most likely to emphasize flexibility. Interestingly, lower-level managers were the least likely to emphasize flexibility.

\begin{tabular}{|c|c|c|c|c|c|c|c|}
\hline \multirow[b]{2}{*}{ Variable } & \multirow[b]{2}{*}{$\begin{array}{l}\text { Non-Management } \\
\quad(N=51)\end{array}$} & \multicolumn{5}{|c|}{ Level of management } & \\
\hline & & $\begin{array}{l}\text { Lower } \\
(N=75)\end{array}$ & $\begin{array}{l}\text { Middle } \\
(N=54)\end{array}$ & $\begin{array}{l}\text { Upper } \\
(N=57)\end{array}$ & $F$-value & Significance & \\
\hline Art & -0.020 & -0.016 & 0.386 & -0.326 & 4.959 & 0.002 & \\
\hline Science & -0.320 & -0.055 & 0.017 & 0.343 & 4.235 & 0.006 & \\
\hline Consistency & -0.032 & -0.028 & 0.326 & -0.242 & 3.143 & 0.026 & \\
\hline Flexible & 0.235 & -0.444 & 0.048 & 0.328 & 8.746 & 0.000 & Table III. \\
\hline Top-down & 0.077 & -0.219 & -0.169 & 0.379 & 4.758 & 0.003 & Strategic philosophy by \\
\hline Bottom-up & 0.255 & -0.124 & 0.201 & -0.256 & 3.578 & 0.015 & management level \\
\hline
\end{tabular}

Philosophy and management level

165 
$\mathrm{MD}$

43,2

166

In one respect, this finding is consistent with an agency perspective (Oswald and Jahera, 1991; Stiles, 2001). As "owners" of the implementation process, middle managers appear to value consistency, which also infers a concern for predictability, stability, and control. Hence, one could argue that middle managers resist strategic change because it challenges existing patterns of behavior and could even threaten job security (Floyd and Wooldridge, 2000).

Alternatively, however, this distinction could be due to the fact that middle managers understand the value of strategic consistency. During times of strategic change, middle managers see firsthand the "casualties" associated with implementing such changes. Hence, the middle management preference for strategic consistency could be due to a close familiarity with the downside of major strategic shifts (Saffold, 1988).

The third proposition was supported. As predicted, top managers and lower-level managers were most likely to view strategy as a top-down approach. In contrast, middle and non-managers perceived strategy formulation more as a bottom-up process.

Although the top management's view that strategy formulation is a top-down process was expected, agreement from lower-level managers was not anticipated. As with the other findings, there are at least two plausible explanations for this distinction. First, supervisory managers may not be as cognizant of the prospects for and value of the participation of managers throughout the organization in the strategy process. As a result, many may continue to view top managers as "they" in terms of their involvement in directing the organization.

Alternatively, lower-level managers may not be satisfied with their past "participation" in strategy formulation and other middle or top management decisions. Complaints concerning the legitimacy of suggestion boxes and participative management styles are not uncommon. Perhaps lower-level managers simply do not view efforts to gain their participation in the process as credible.

From a broader perspective, several additional points are noteworthy. Non-managers tended to emphasize flexibility and a bottom-up approach to strategy. Lower managers did not score high on any of the scales, and were notably the least supportive of a flexible perspective. Middle managers tended to see strategy as an art and emphasized consistency and a bottom-up approach. Top managers strongly favored a scientific, flexible, top-down approach to strategy.

\section{Conclusions and directions for future research}

Scales to measure three key philosophical dimensions associated with strategy formulation were developed and tested in this study. Findings suggest that one's management level influences one's strategic philosophy. Specifically, top-, middle-, and lower-level managers tend to view the strategy-making process in different ways, presumably because of their different job responsibilities, experiences, and organizational perspectives.

A number of future research issues have been identified. First, the link between managerial level and strategic philosophy could have strong implications for management development programs. Additional research is needed, however, to explain the link in greater detail and identify a taxonomy of factors that affect the relationship. 
Second, the results suggested that management level may be a key determinant of one's strategic philosophy, but a more comprehensive examination of other prospective factors could enhance our understanding of the phenomenon. Potential moderating or mediating roles of content-related issues could also be examined (Rettinger and Hastie, 2001). Additional studies could also consider factors such as age, level of management education, organizational experience, industrial experience, functional background, and gender.

Third, the present study did not consider whether one strategic perspective might be inherently superior to another or dependent on the specific situation and the environment in which the organization operates. For example, viewing strategy as a science may be more effective in stable industries where executives possess a significant amount of objective information and future prospects are fairly predictable. In contrast, viewing strategy as an art may be more effective in turbulent environments where the future of the industry and factors affecting it are not commonly known. Such assertions remain untested.

Finally, multiple possible explanations for each of the findings associated with the three propositions have been suggested. Additional research is necessary not only to confirm the existence of these relationships, but also to provide additional insight into the correct explanations for them. In addition, some of relationships associated with strategic philosophy may be associated with factors such as industry, organizational size, or national culture. A broader data collection - especially one that includes respondents from multiple nations - would allow such prospective relationships to be tested.

\section{References}

Barney, J.B. (2001), "Is the resource-based 'view' a useful perspective for strategic management research? Yes", Academy of Management Review, Vol. 26, pp. 41-56.

Beaver, G. (2003), "Beliefs and principles: the compass in guiding strategy", Strategic Change, Vol. 12, pp. 1-5.

Boeker, W. (1989), "Strategic change: the effects of founding and history", Academy of Management Journal, Vol. 32, pp. 489-515.

Brockmann, E.N. and Anthony, W.P. (2002), "Tacit knowledge and strategic decision making”, Group \& Organization Management, Vol. 27, pp. 436-55.

Cronbach, L.J. (1951), "Coefficient alpha and the internal structure of tests", Psychometrica, Vol. 16, pp. 297-334.

Currie, G. (1999), "The influence of middle managers in the business planning process: a case study in the UK NHS”, British Journal of Management, Vol. 10 No. 2, pp. 141-55.

Davis, D. and Fisher, T. (2002), "Attitudes of middle managers to quality-based organizational change”, Managing Service Quality, Vol. 12, pp. 405-13.

Fenton-O'Creevy, M. (2001), "Employee involvement and the middle manager: saboteur or scapegoat?", Human Resource Management Journal, Vol. 11 No. 1, pp. 24-40.

Floyd, S.W. and Wooldridge, B. (2000), Building Strategy from the Middle: Reconceptualizing Strategy Process, Sage Publications, London.

Ford, C.M. and Gioia, D.A. (2000), "Factors influencing creativity in the domain of managerial decision making", Journal of Management, Vol. 26, pp. 705-32.
Philosophy and management level 
$\mathrm{MD}$

43,2

168
Foxman, E.R., Muehling, D.D. and Berger, P.W. (1990), "An investigation of factors contributing to consumer brand confusion”, Journal of Consumer Affairs, Vol. 24, pp. 170-89.

Frishammar, J. (2003), "Information use in strategic decision making", Management Decision, Vol. 41, pp. 318-26.

Gannon, M.J., Smith, K.G. and Grimm, C. (1992), "An organizational information-processing profile of first movers", Journal of Business Research, Vol. 25, pp. 231-41.

Greiner, L.E. and Bhambri, A. (1989), "New CEO intervention and dynamics of deliberate strategic change", Strategic Management Journal, Vol. 10, pp. 67-86.

Grewel, R. and Tansuhaj, P. (2001), "Building organizational capabilities for managing economic crisis: the role of market orientation and strategic flexibility", Journal of Marketing, Vol. 65 No. 2, pp. 47-80.

Guth, W.D. and Macmillan, I.C. (1986), "Strategy implementation versus middle management self-interest", Strategic Management Journal, Vol. 7, pp. 313-27.

Hambrick, D.C. and Fredrickson, J.W. (2001), “Are you sure you have a strategy?”, Academy of Management Executive, Vol. 15 No. 4, pp. 48-59.

Hamel, G. (1996), “Strategy as revolution”, Harvard Business Review, July-August, pp. 69-82.

Harman, H.H. and Jones, W.H. (1966), "Factor analysis by minimizing residuals", Psychometrica, Vol. 31, pp. 351-68.

Hart, S.L. (1992), “An integrative framework for strategy-making processes”, Academy of Management Review, Vol. 17, pp. 327-51.

Hendry, J. (2000), "Strategic decision making, discourse, and strategy as social practice", Journal of Management Studies, Vol. 37, pp. 955-77.

Hitt, M.A., Keats, B.W. and DeMarie, S.M. (1998), "Navigating in the new competitive landscape: building strategic flexibility and competitive advantage in the 21st century", Academy of Management Executive, Vol. 22 No. 12, pp. 22-42.

Hornsby, J.S., Kuratko, D.F. and Zahra, S.A. (2002), "Middle managers' perception of the internal environment for corporate entrepreneurship: assessing a measurement scale", Journal of Business Venturing, Vol. 17, pp. 253-73.

Huffman, B. (2001), "What makes a strategy brilliant?", Business Horizons, July-August, pp. 13-20.

Kotey, B. and Meredith, G.G. (1997), "Relationships among owner/manager personal values, business strategies, and enterprise performance”, Journal of Small Business Management, Vol. 35 No. 2, pp. 37-61.

Kraatz, M.S. and Zajac, E.J. (2001), "How organizational resources affect strategic change and performance in turbulent environments: theory and evidence", Organizational Science, Vol. 12, pp. 632-57.

Kuratko, D.F., Montagno, R.V. and Hornsby, J.S. (1990), "Developing an intrapreneurial assessment instrument for an effective corporate entrepreneurial environment", Strategic Management Journal, Vol. 11, pp. 49-58.

Lado, A., Boyd, N. and Wright, P. (1992), “A competency based model of sustained competitive advantage: toward a conceptual integration”, Journal of Management, Vol. 18, pp. 77-91.

Lieberman, M.B. and Montgomery, D.B. (1988), "First-mover advantages", Strategic Management Journal, Vol. 9, pp. 41-58.

Loken, B., Ross, I. and Hinkle, R.L. (1986), "Consumer confusion of origin and brand similarity perceptions”, Journal of Public Policy and Marketing, Vol. 5, pp. 195-211. 
Marginson, D.E.W. (2003), "Management control systems and their effect on strategy formation at middle-management levels: evidence from a UK organization”, Strategic Management Journal, Vol. 23, pp. 1019-31.

Markoczy, L. (2001), "Consensus formation during strategic change", Strategic Management Journal, Vol. 22, pp. 1013-31.

Mascarenhas, B. (1992), "First mover effects in multiple dynamic markets", Strategic Management Journal, Vol. 13, pp. 237-43.

Philosophy and management level

Mezias, J., Grinyer, P. and Guth, W.D. (2001), “Changing collective cognition: a process model for strategic change”, Long Range Planning, Vol. 34, pp. 71-95.

Miles, R.E. and Snow, C.C. (1978), Organizational Strategy, Structure, and Process, West, New York, NY.

Mintzberg, H. (1987), “Crafting strategy”, Harvard Business Review, pp. 66-75, July-August.

Mintzberg, H. and Waters, J.A. (1985), “Of strategies, deliberate and emergent”, Strategic Management Journal, Vol. 6, pp. 257-72.

Nichol, R.L. (1992), "Get middle managers involved in the planning process", Journal of Business Strategy, Vol. 13 No. 3, pp. 26-32.

Oswald, S.L. and Jahera, J.S. (1991), "The influence of ownership on performance: an empirical study", Strategic Management Journal, Vol. 12, pp. 321-6.

Parnell, J.A. (1994), "Strategic consistency versus flexibility: does strategic change really enhance performance?”, American Business Review, Vol. 12 No. 2, pp. 22-30.

Parnell, J.A. (1997), "New evidence in the generic strategy and business performance debate: a research note", British Journal of Management, Vol. 8, pp. 175-81.

Parnell, J.A. (2000), "Reframing the combination strategy debate: defining forms of combination", Journal of Applied Management Studies, Vol. 9 No. 1, pp. 33-54.

Peter, J.P. (1979), "Review of psychometric basics and recent marketing practices", Journal of Marketing Research, Vol. 16, pp. 6-17.

Petersen, B. and Welch, D.E. (2000), "Creating meaningful switching options in international operations", Long Range Planning, Vol. 33, pp. 688-705.

Porter, M.E. (1985), Competitive Advantage, Free Press, New York, NY.

Priem, R.L. and Butler, J.E. (2001), "Is the resource-based 'view' a useful perspective for strategic management research?”, Academy of Management Review, Vol. 26, pp. 22-40.

Rettinger, D.A. and Hastie, R. (2001), "Content effects on decision making", Organizational Behavior and Human Decision Processes, Vol. 85, pp. 336-59.

Saffold, G.S. III (1988), "Culture, traits, strength, and organizational performance: moving beyond strong culture", Academy of Management Review, Vol. 13, pp. 546-58.

Smircich, L. and Stubbart, C. (1985), "Strategic management in an enacted world", Academy of Management Review, Vol. 10, pp. 724-36.

Stiles, P. (2001), "The impact of board on strategy: an empirical examination", Journal of Management Studies, Vol. 38, pp. 627-50.

Thakur, M. (1998), "Involving middle managers in strategy making", Long Range Planning, Vol. 31, pp. 732-41.

Trinh, H.Q. and O'Connor, S.J. (2002), "Helpful or harmful? The impact of strategic change on the performance of US urban hospitals", Health Services Research, Vol. 37, pp. 145-71.

Turnbull, S. (2001), "Corporate ideology - meanings and contradictions for middle managers", British Journal of Management, Vol. 12, pp. 231-42. 
$\mathrm{MD}$

43,2

170

Van Der Velde, M.E.G. and Jansen, P.G.W. (1999), "Managerial activities among top and middle managers: self versus other perceptions", Journal of Applied Management Studies, Vol. 8, pp. 161-74.

Wai-Kwong, F.Y., Priemn, R.L. and Cycyota, C.S. (2001), "The performance effects of human resource managers' and other middle managers' involvement in strategy making under difference business-level strategies: the case of Hong Kong”, International Journal of Human Resource Management, Vol. 12, pp. 1325-46.

Walsh, J.P. and Fahey, L. (1986), "The role of negotiated belief structures in strategy making”, Journal of Management, Vol. 12, pp. 325-38.

Webb, J. and Dawson, P. (1991), "Measure for measure: strategic change in an electronic instruments corporation", Journal of Management Studies, Vol. 28, pp. 191-206.

Wernerfelt, B. and Karnani, A. (1987), "Competitive strategy under uncertainty", Strategic Management Journal, Vol. 8, pp. 187-94.

Westphal, J.D. and Fredrickson, J.W. (2001), "Who directs strategic change? Director experience, the selection of new CEOs, and change", Strategic Management Journal, Vol. 22, pp. 1113-37.

Wooldridge, B. and Floyd, S.W. (1990), "The strategy process, middle management involvement, and organizational performance”, Strategic Management Journal, Vol. 11, pp. 231-41. 